\title{
ANALIZA MODELA SLABLJENJA POSLOVANJA KROZ MODELE ŽIVOTNOG CIKLUSA PODUZEĆA: PREGLED LITERATURE
}

\author{
Blaženka Hadrović Zekić*, Karlo Lukić \\ Ekonomski fakultet u Osijeku, Gajev trg 7, Osijek, Hrvatska
}

\begin{abstract}
Apstrakt:
U radu se obrađuje pojam i odabrani modeli slabljenja poslovanja poduzeća, u literaturi poznatog kao proces propadanja. Problemi u poslovanju poduzeća mogu se podijeliti na tri stupnja, od (1) sjemena problema (eng. seed of decline), preko (2) neaktivnosti ili pogrešnih aktivnosti koji izazivaju krize unutar poduzeća, do (3) rješenja problema koje se završava kao (a) preobrazba, (b) povezivanje, ili (c) stečaj poduzeća. Također, u radu su razrađeni uzroci problema koji izazivaju slabljenje poslovanja kroz proučavanje životnog ciklusa poduzeća u kojemu je slabljenje često iscrpljujući proces.
\end{abstract}

Ključne reči:

slabljenje poslovanja,

organizacijska promjena.

\section{UVOD}

Cilj poslovanja svakog poduzeća je ostvarenje dobitka. Nažalost, sva poduzeća ne uspijevaju ostvariti taj cilj tako da je u poslovnom svijetu, smrt odnosno bankrot još uvijek taboo tema. Znanstvena i stručna literatura (npr. Peter Drucker, Jack Welch) s područja menadžmenta, posebice strateškog upravljanja prvenstveno je okrenuta rastu poduzeća. Propast poduzeća ima negativan utjecaj na sve dionike (eng. stakeholder), tako da analiza slabljenja poduzeća kao i utjecaj propadanja na dionike sve više zanima veliki broj znanstvenika (osim mikro i makro ekonomista, zanima i psihologe, sociologe, pravnike...). S obzirom da propast poduzeća ne dolazi iznenada, znanstvenici imaju interdisciplinaran pristup problemu poslovanja poduzeća.

Ekonomska kriza nije uzrok propadanja poduzeća već okidač. Uzroci problema nastaju unutar samog poduzeća, odnosno usled nedostatka kontinuiranog praćenja i pravodobnih reakcija koje bi ublažile, ako ne i spriječile razvoj daljnjih problema. Kada je ugrožen sam opstanak poduzeća, kada se u danima računa vrijeme do potpunog prestanka poslovanja, kada čak ni standardni načini upravljanja nisu dostatni, uprave poduzeća počinju shvaćati važnost primjene metoda i instrumenata ranog upozorenja na probleme poduzeća. Nepravodobna i neodgovarajuća reakcija uprave poduzeća dovodi do eksponencijalnog rasta problema u poslovanju, produbljivanja krize te u doba ekonomske krize dolazi do sve većeg broja stečaja poduzeća.

\section{PREDMET ISTRAŽıVANJA}

Pogrešno je poistovjećivanje pojmova problema (Žugaj et al., 2004) vezanog za sporo opadanje poslovanja ili nazadovanja (Sikavica \& Novak, 1999), (eng. organizational decline, dissolution) kao zasebnog područja izučavanja, s istraživanjima i literaturom o stečaju (eng. bankruptcy, business failure) ili vremenskom neograničenosti poslovanja (eng. going-concern) jer se radi o terminima koji govore o različitim financijskim stanjima poduzeća. Naime, poduzeća koja su došla do stečaja ili kod kojih se procjenjuje ograničenost vremena poslovanja već su prošli fazu problema i mala je vjerojatnost opstanka. Drugim riječima, poduzeće s problemima u poslovanju nalazi se pred ključnom prekretnicom svog poslovanja jer je započelo slabljenje resursne osnove poduzeća (npr. kupci, zaposlenici, financijska imovina) (Adler \& Chaston, 2002).

Nadalje, često se poistovjećuje pojam problema u poslovanju sa smanjenjem obujma poslovanja (eng. downsizing) iako ovi pojmovi predstavljaju suprotnost. Naime, problem se razvija unutar poduzeća, npr. on je slučajan (nenamjeran) dok je smanjenje obujma poslovanja strateška akcija koja se poduzima unutar poduzeća te može biti i funkcionalna i namjerna. Drugim riječima, poduzeće može smanjivati opseg poslovanja bez postojanja problema u poslovanju, a isto tako može postojati problem u poslovanju bez smanjivanja opsega poslovanja.

U hrvatskoj znanstvenoj i stručnoj literaturi najčešće se za probleme u poslovanju poduzeća koristi termin poslovna 
kriza (Osmanagić Bedenik, 2003). U ovom radu je izbjegnuto poistovjećivanje termina slabljenja ili problema u poslovanju (poslovne teškoće) (Novak, 2003) i poslovne krize zbog šireg obuhvata pojma krize ${ }^{1}$ (prijeloma) koji zahtijeva trenutnu reakciju. Također, sukladno svjetskoj literaturi na engleskom jeziku, pod pojmom poslovna kriza (eng. organizational crisis, business crisis) podrazumijeva se „tehnološka nesreća, kriza propadanja i razvojna kriza" (KovoorMisra et al., 2001, p. 77), odnosno „promjena - bilo nagla ili postupna - koja donosi neki ozbiljan problem koji treba odmah riješit" (Luecke, 2005, p. 15), dok „pojam propadanje (slabljenje, op.a.) po svojoj definiciji uključuje ograničene resurse te pritiske za rezovima" (Cameron et al., 1987, p. 127). U radu su proučeni pojam, vrste i odabrani modeli slabljenja poslovanja poduzeća u literaturi nazvanog i procesom propadanja.

\section{PREGLED DOSADAŠNJIH ISTRAŽIVANJA PROBLEMA U POSLOVANJU PODUZEĆA}

Problem u poslovanju koji ugrožava egzistenciju poduzeća može zahvatiti poduzeće bilo koje veličine, poznato i nepoznato, u bilo kojoj industrijskoj grani. Svako slabljenje poslovanja može biti predvidljivo ukoliko uprava redovito prati promjene poslovanja poduzeća i prijetnje iz okruženja te je spremna mijenjati poslovanje već na rane signale. Ukoliko uprava, zanesena trenutnim uspješnim poslovanjem, ne vodi računa o mogućim uzrocima problema, tada se oslabljeno poslovanje može „nepredviđeno” pojaviti. Nadvladati probleme u poslovanju ovisi o vrsti i stupnju problema te sposobnosti uprave u pronalasku rješenja. Kvalitetnije razumijevanje problema poslovanja poduzeća i analiza njegovih uzroka ključni su za shvaćanje relevantnosti izučavanja ove problematike.

\subsection{Uvod u predviđanje poslovnih poteškoća}

Problem (grč. problema od proballo - spominjem, predlažem) kao pojam znači „teoretsko ili praktično pitanje koje zahtjeva rješenje; (...) zadaća uopće, prijeporno pitanje, zagonetka" (Klaić, 1966, p. 1000-1001). Problem u poslovanju definiran je kao izostanak „predviđanja, prepoznavanja, izbjegavanja, neutralizacije ili prilagođavanja vanjskim i unutarnjim pritiscima koji ugrožavaju (...) dugoročno preživljavanje“ (Jones, 2009, p. 320).

„Ako poduzetnik (...) neefikasno motri na poslovanje, pozicija uspjeha bit će reducirana” (Barković, 2009, p. 166). Uprave poduzeća se svakodnevno susreću s problemima, no slabljenje poslovanja nikada ne uzrokuje jedan čimbenik već dva ili više njih koji nastaju kao posljedica zanemarivanja ranih signala problema. Problem u poslovanju može nastati uslijed utjecaja čimbenika iz vanjskog okruženja ili kao rezultat određenih slabosti unutar samog poduzeća. Ako

1 nepredviđen događaj koji utječe na poslovanje, a koji uprava ne može predvidjeti ili spriječiti (npr. potres, požar). uprava na vrijeme prepozna znakove upozorenja te poduzme odgovarajuće korektivne mjere, promjene će biti slabijeg intenziteta i neće biti opasne za opstanak poduzeća. No, ukoliko uprava zanemari rane signale ili ne pronađe adekvatna rješenja, problem u poslovanju može se razviti te rezultirati čak i likvidacijom poduzeća (propadanjem u crnu rupu).
Slika 1. Dijagnostički sustav propasti poduzeća

stic framework of organizational failure) (Samuel, 2009, p. 7)

Riječi organizacija (u smislu poduzeća $)^{2}$ i organizam ${ }^{3}$ imaju isti korijen riječi organ (grč. organon - oruđe, sprava, stroj, dio tijela), pa se prema Klaiću gotovo mogu smatrati sinonimima jer u drugom značenju organizma koristi „često isto što i organ, tj. ustroj, sastav, sklop, grupa ljudi povezanih u određenu svrhu" (Klaić, 1966, p. 897), tako da je korištenje analogije prirodoslovlja (organizam) u teoriji poduzetništva (organizacije) gotovo dovelo do terminološkog poistovjećivanja poduzeća (organizacije) sa živim bićem (organizmom). U tom smislu počele su se koristiti analogije kao što su npr. ponašanje organizacije (eng. organizational behaviour), organizacijska promjena (eng. organizational change), efektivnost poduzeća (eng. organizational effectiveness), organizacijska evolucija (eng. organizational evolution), organizacijski rast (eng. organizational growth), organizacijska ideologija (eng. organizational ideology), sociologija organizacije (eng. organizational sociology), pa do organizacijske smrti (eng. organizational death) ili organizacijske patologije (eng. organizational pathology) (Samuel, 2009).

\section{4. ŽIVOTNI CIKLUS PODUZEĆA}

Teorije poduzetništva su općenito temeljene na pretpostavci rasta tako da su sukladne pretpostavci da su znanstvenici zaokupljeni istraživanjem rasta i njegovih efekata. Tri su razloga proučavanja rasta:

1) postoji pozitivan odnos između veličine i starosti poduzetnika; sukladno tome, glavna težnja poduzeća tijekom sazrijevanja usmjerena je na savladavanje rasta;

2) veličina je poželjna odlika poduzeća - npr. što veći to bolji;

3) rast je sinonim efektivnosti.

Zbog toga su teorije razvoja poduzeća do 1980-tih zapostavljale proučavanje slabljenja poslovanja (Whetten, 1980).

2 "grupa ljudi sjedinjenih zajedničkim programom, ciljem ili zadatkom" (Klaić, 1966, p. 897)

3 „živo biće, tijelo organske prirode (...) koje se odlikuje: izmjenom tvari, rastom, razmnožavanjem, sposobnošću reagiranja na podražaje, prilagodljivošću životnim uvjetima, posebnim kemijskim sastavom koji stvara protoplazmu" (Klaić, 1966, p. 897) 
Od poduzeća s dobrom upravom očekuje se kontinuirani rast iz godine u godinu. Ove teorije koje podrazumijevaju rast i širenje poduzetnika utjecale su na financijske analitičare tako da rast poduzetnika ukazuje na uspješno upravljanje. Ipak, iluzorno je za očekivati da će poduzetnici rasti u nedogled i da se neće susretati s problemima.

Početkom 1950-tih Edith Tilton Penrose, pišući o teoriji rasta poduzeća analizirala je upotrebu analogije prirodoslovlja u teoriji poduzetništva (organizacija). Naime, ekonomisti su se oduvijek oslanjali na analogije iz prirodoslovlja kako bi olakšali razumijevanje ekonomskih pojava. U doba Penroseove najčešće korištene prirodoslovne analogije bile su životni ciklus, analiza održivosti ${ }^{4} \mathrm{i}$ homeostaza ${ }^{5}$ poduzeća koje su se zadržale do danas. Naime, kao i u prirodi, analogije ne gledamo kao svaku zasebno, jer životni ciklus koji prati nastanak, rast i odumiranje poduzeća analizira se dugoročno, za razliku od održivosti i homeostaze koje karakterizira kratkoročna analiza (Penrose, 1952). Drugim riječima, rano otkrivanje problema u poslovanju poduzeća sprječava eventualnu nemogućnost ostvarivanja pozitivnog dobitka (održivost) pomoću kojeg se može doći do ukidanja ravnoteže unutar poduzeća (homeostaza), što utječe na ukupno poslovanje, odnosno životni ciklus poduzeća.

Model životnog ciklusa poduzeća temelji se na pretpostavci da je živi organizam (poduzeće, organizacija), kao i ostali, otvoreni sustav koji je pod utjecajem vremena i ostalih sustava u okolini. Iz toga proizlazi da svako poduzeće ima svoj nastanak, rast (pad) te starenje. Elementi kroz koje se prati razvoj poduzeća mogu biti: starost, veličina organizacije, stanje evolucije i revolucije, te stopa rasta gospodarske grane kojoj pripada poduzeće. Svako poduzeće u svom životnom ciklusu nastaje kroz poduzetničku ideju. Osnivanjem i razradom poduzetničke ideje se rađa, širenjem poslovanja raste, odnosno živi, a nepravodobnim rješavanjem problema ulazi u krizu te se na kraju gasi, tj. umire, odlazi u stečaj. Kao što je ranije napisano, za poduzeća su opasniji prelasci u viši stadij jer izazvaju velike probleme unutar poduzeća. S pristupa uprave, vrlo je teško voditi poduzeće kroz sve faze njegovog rasta i razvoja. Drugim riječima, samo u rijetkim slučajevima ista uprava uspijeva voditi poduzeće kroz njegov razvoj, a da ne dođe u ozbiljnu krizu. Ulazak u novu fazu rasta obično je ulazak u krizu upravljanja koju treba na vrijeme primijetiti.

Znanstvena istraživanja s područja razvoja modela životnih ciklusa poduzeća počinju 1967. godine s modelima Anthony-a Downs-a koji je proučavao ustanove te Lippitt-a i Schmidt-a koji su u isto vrijeme razvili model u privatnom sektoru. Analizirajući Tablicu 2. vidljivo je da se spomenuti modeli nadovezuju i nadopunjuju, odnosno da se nisu razvijali nezavisno jedan od drugoga, ali su ipak svaki za sebe zasebni jer je i svaki autor nadograđivao prethodni model sukladno svojim istraživanjima. Također, u tablici nisu obrađeni svi modeli životnih ciklusa već samo značajni s pogleda izučavanja problema u poslovanju poduzeća.

Model životnog ciklusa Anthony-a Downs-a iz 1967. sastoji se od tri temeljne etape rasta i razvoja državnih ureda (ustanova). Prema njegovoj raščlambi, prvu fazu - nastanak, karakterizira jedan od četiri načina nastanka; ostvarivanje ideja karizmatičnog vođe, ispunjavanje specifične funkcije za koju grupa uoči kao potrebitu, odvajanje od postojeće birokracije, ili kroz poduzetnički duh primjenjivanje potpuno

4 prilagođavanja uvjetima okoline poduzetnika, temeljeno na Darwinovoj teoriji evolucije

5 održavanje stalnih uvjeta u unutarnjoj okolini nove politike. $U$ fazi nastanka državni uredi dijele tri sličnosti - u početku dominiraju pobornici ili fanatici, prolaze kroz rane faze brzog rasta, i trebaju odmah tražiti izvore vanjske podrške za preživljavanje i autonomiju. Ostvarivanjem autonomije ulazi se u drugu fazu - nagli rast, koja uključuje snažnu ekspanziju te naglasak na inovaciji i kreativnosti. Konačno, treća faza je stanje usporavanja u kojem dolazi do argumentirane tipizacije i formalizacije pravila i procedura te naglasku na predvidivosti i koordinaciji. Ukratko, Downsov model promatra državnu upravu kako raste od uspostavljanja zakonitosti, preko inovativnosti i širenja, i konačno do formalizacije i kontrole. (Žugaj et al., 2004; Sample Article Summaries; Quinn \& Cameron, 1983)

Gordon L. Lippitt i Warren H. Schmidt (1967) razvili su jedan od najranijih modela životnog ciklusa u privatnom sektoru (poduzetništvu). Oni također govore o tri razvojne faze životnog ciklusa poduzeća: rađanje, mladost i zrelost. U fazi rađanja karakteristično je kreiranje operativnog sustava poduzeća te učenje postaje održivo, dok fazu mladosti karakterizira razvoj stabilnosti i reputacije kako bi zrelost bila usmjerena na postizanje jedinstvenosti i prilagođavanje širenja područja djelovanja. Ovaj model detaljno opisuje šest glavnih upravljačkih briga koje se mijenjaju ovisno o napredovanju poduzeća od stadija do stadija (Žugaj et al., 2004; Lippitt \& Schmidt, 1967; Quinn \& Cameron, 1983).

Model Bruces R. Scott-a (1971) razlikuje tri tipa korporativnih oblika koji prate povijesni slijed. Model prikazuje poduzeće u smislu napretka od neformalnih izvedbi i pokušaja, do formaliziranih birokracija te naposljetku do raznovrsnih konglomerata, odnosno elemenata. U prvom stadiju poduzeću nedostaje strukturiranosti, jedinstvenih proizvoda te kontrole osoblja. Za drugi stadij u Scott-ovom životnom ciklusu poduzeća karakteristične su funkcionalna specijalizacija i usmjeravanje, institucionalizirano istraživanje i sustav nagrađivanja koji nije utemeljen na osobnoj bazi. Karakteristike trećeg stadija su brojne linije proizvoda, probijanje na različita tržišta te usmjeravanje na rast i adaptaciju (Quinn \& Cameron, 1983).

Larry Greiner (1972) je ustanovio da se unutar poslovanja poduzeća događaju određeni procesi u pet životnih faza. Prva je kreativnost, gdje je poduzeće orijentirano na proizvodnju odgovarajućih proizvoda, odnosno usluga, neformalno komuniciranje i strukturu te na primjereno plaćanje rada. Sljedeća faza usmjerenosti (direktive) u kojoj je najizraženije ustanovljavanje funkcionalne strukture, na specijalizaciju zadataka i odgovarajuću formalizaciju uloga i politika u poduzeću. Nakon usmjerenosti, slijedi faza delegiranja u kojoj organizacija decentralizira strukturu, delegira odgovarajuće odluke nižem menadžmentu, i pristupa rukovođenju putem izuzetaka (eng. management by exception). U fazi koordinacije dolazi do pojave novih sustava planiranja, programa podjele dobitka itd. U posljednjoj, fazi suradnje, svoj rad organizacija oslanja na specifične timove, spontanost u upravljanju, sukobe u međuljudskim odnosima, samodisciplinu, sustav više ciljeva i sl. (Quinn \& Cameron, 1983).

William Rockwell Torbert-ov (1974) model temelji se na individualnim mentalitetima, odnosno načinima razmišljanja članova poduzeća. Poduzeće napreduje kada članovi steknu iskustvo i postanu svjesni uzročnih čimbenika i dinamike rada poduzeća te kada razviju veći kapacitet za osobnu i međuljudsku učinkovitost. Utvrđena pravila i struktura dominiraju dok se ne dogodi neki novi napredak, poboljšanje, 
Tablica 1. Pregled modela životnog ciklusa poduzetnika

\begin{tabular}{|c|c|c|c|}
\hline Rađanje i djetinjstvo & Mladost & Zrelost & Starost \\
\hline \multicolumn{4}{|c|}{ Downs (1967.): Motivacija za rast } \\
\hline Borba za autonomiju & Ubrzani rast & Usporavanje & \\
\hline \multicolumn{4}{|c|}{ Lippitt \& Schmidt (1967.): Kritični upravljački problemi } \\
\hline Rađanje & & Mladost & Zrelost \\
\hline \multicolumn{4}{|c|}{ Scott (1971.) Strategija i struktura } \\
\hline Faza 1 & & Faza 2 & Faza 3 \\
\hline \multicolumn{4}{|c|}{ Greiner (1972.): Problemi koje vode evoluciji i revoluciji } \\
\hline & Faza kreativnosti & Faza usmjeravanja & $\begin{array}{l}\text { Faza delegiranja } \\
\text { Faza koordinacije } \\
\text { Faza suradnje }\end{array}$ \\
\hline \multicolumn{4}{|l|}{ Torbert (1974) } \\
\hline Maštanje & $\begin{array}{l}\text { Ulaganje } \\
\text { Određivanje }\end{array}$ & $\begin{array}{l}\text { Eksperimentiranje } \\
\text { Prethodno određena učinkovitost }\end{array}$ & $\begin{array}{l}\text { Javno odabrana struktura } \\
\text { Utemeljenje zajednice } \\
\text { Opuštene discipline }\end{array}$ \\
\hline \multicolumn{4}{|c|}{ Lyden (1975.) Funkcionalni problemi } \\
\hline $\begin{array}{l}\text { Prva faza } \\
\text { Druga faza }\end{array}$ & & $\begin{array}{l}\text { Treća faza } \\
\text { Četvrta faza }\end{array}$ & \\
\hline \multicolumn{4}{|c|}{ Katz \& Kahn (1978.) Organizacijska struktura } \\
\hline & Faza jednostavnog sustava & Faza stabilne organizacije & Faza potpomognute strukture \\
\hline \multicolumn{4}{|c|}{ Quinn \& Cameron (1983.): Integracija modela } \\
\hline Poduzetnička faza & Faza kolektivnog duha & Faza formalizacije (diferencijacije) & Faza elaboracije (usavršavanja) \\
\hline \multicolumn{4}{|l|}{ Kimberly (1979) } \\
\hline Prva faza & $\begin{array}{l}\text { Druga faza } \\
\text { Treća faza }\end{array}$ & Četvrta faza & \\
\hline \multicolumn{4}{|c|}{ Adizes (1979., 1988.): Glavne organizacione aktivnosti } \\
\hline $\begin{array}{l}\text { Udvaranje } \\
\text { Doba povoja }\end{array}$ & $\begin{array}{l}\text { Go-go } \\
\text { Adolescencija }\end{array}$ & $\begin{array}{l}\text { Top forma } \\
\text { Stabilnost }\end{array}$ & $\begin{array}{l}\text { Aristokracija } \\
\text { Rana birokracija } \\
\text { Birokracija } \\
\text { Smrt }\end{array}$ \\
\hline \multicolumn{4}{|c|}{ Quinn, Cameron \& Greiner (1992.): Problemi koje vode evoluciji i revoluciji } \\
\hline $\begin{array}{l}\text { Faza kreativnosti } \\
\text { Faza usmjeravanja }\end{array}$ & Faza delegiranja & Faza koordinacije & $\begin{array}{l}\text { Faza suradnje } \\
\text { Faza povezivanja }\end{array}$ \\
\hline
\end{tabular}

Izvor: Prilagođeno prema (Quinn \& Cameron, 1983; Žugaj et al., 2004)

obnova ili prilagodba. Prvi stupanj je maštanje koji se odnosi na vizije pojedinaca, oluju mozgova (eng. brain-storming), slobodne otvorene razgovore i različite percepcije unutar poduzeća. Za drugi stupanj, ulaganje, karakteristična su individualna ulaganja, neodređeni stil upravljanja, ispitivanje dubine i vjerodostojnosti privrženosti. Treći je stupanj determinacija ili određivanje tijekom kojeg se uspostavljaju struktura i zajednički ciljevi. U četvrtom stupnju eksperimentiranja - vodstvo, uloge, planovi i rasporedi su uspostavljeni, a karakterizira ga donošenje racionalnih odluka. Peti stupanj - prethodno određene učinkovitosti odnosi se na usmjeravanje pozornosti ostvarivanju zadanih ciljeva, tako da su uspostavljeni struktura i autoritet. Za šesti stupanj javno odabrane strukture karakteristične su kreativnost, inovacija, fleksibilnost i prodiranje u značajnije odluke i pitanja. Sedmi je stupanj utemeljenje zajednice tijekom kojeg se članovi poduzeća povezuju, razvijaju slične načine razmišljanja, dijele ista uvjerenja i ciljeve. Tijekom osmog stupnja - opuštene discipline - poduzeće traži nove izazove, „obnavlja” samo poduzeće i njegove članove (usavršavanje) (Quinn \& Cameron, 1983).

Prema Fremont James Lyden-u (1975) poduzeća se moraju usmjeriti na različite probleme u poslovanju, u različitim stadijima razvoja kao što su prilagodba okolini, nabavka kapitala i izvora, ostvarenje ciljeva i održavanje strukture. Razvoj i napredak kreću se od inovacije do stabilnosti i institucionalizacije. Lyden je životni ciklus podijelio u četiri faze razvoja poduzeća. U prvoj se fazi poduzeće nastoji prilagoditi i izgraditi zahtjevima vanjskih uvjeta, druga stavlja naglasak na potrebe za odgovarajućim resursima te razvoj radnih procedura. Za treću fazu bitna je važnost učinkovite proizvodnje i ostvarivanja planiranih ciljeva, dok se u četvrtoj naglašava održanje strukture i ostvarivanje ciljeva (Quinn \& Cameron, 1983).

Daniel Katz i Robert L. Kahn (1978) ponudili su model životnog ciklusa poduzeća koji odražava razvoj organizacijske strukture, a sastoji se od:

1) faze jednostavnog sustava,

2) faze stabilne organizacije, te

3) faze potpomognute strukture.

U fazi jednostavnog sustava govori se o sustavu u kojem se ostvaruje kooperacija odgovarajućih napora koja je temeljena na očekivanjima i zajedničkim potrebama članova organizacije. Faza stabilne organizacije je pak orijentirana na sustav koordinacije i formalizacije, nadalje na autoritet, neformalnu strukturu, i sl. Na kraju, faza potpomognute strukture, stvara određene adaptivne sustave i mehanizme koji joj omogućavaju uspješno djelovanje u određenoj okolini (Žugaj et al., 2004, str. 162; Quinn \& Cameron, 1983).

John R. Kimberly (1979) analizira životni vijek poduzeća u četiri faze. Prva faza, po njegovu mišljenju, odvija se prije nego što je organizacija zapravo započela s radom, a taj stadij bi trebao obuhvaćati formiranje ideologije i potragu 
za izvorima financiranja. U drugoj fazi organizacija nastoji osigurati potporu vanjske okoline, pronalazak i zapošljavanje odgovarajućih djelatnika, uspostavljanje podrške iz okoline te donošenje čestih i diskretnih odluka. Treću fazu poduzeća formulira kreiranje identiteta, visoko ulaganje, (vremena i razmišljanja) članova organizacije - posvećenost i predanost, potraga za misijom i vizijom organizacije, odnosno razvija se sustav kolektivnog djelovanja, kolektivne odgovornosti i teži što uspješnije ostvariti vlastitu misiju poduzeća. Formaliziranu strukturu, definirana pravila i poslovne politike, stabilizirane vanjske veze, internu konkurenciju i konzervativne tendencije organizacija ima u institucionalizaciji ili četvrtoj fazi (Quinn \& Cameron, 1983).

Ichak Adizes, poznati znanstvenik i teoretičar menadžmenta i organizacijske terapije poduzeća, u svojim je istraživanjima (1979) objavio način razvoja poduzeća kroz stadije zbog promjena u težnjama (naglasku). Ovo je jedini model koji je razvio stadije sazrijevanja i stadije opadanja, pri čemu tvrtka sazrijeva od začetka do zrelosti, a opada od zrelosti do „smrti”. Po Adizesu, prema kraju organizacije dovode pretjerana usmjerenost na stabilnost, administraciju, pravila i procedure. Njegove faze organizacije su opisima najsličnije ljudskom životu (Quinn \& Cameron, 1983; Žugaj et al., 2004).

Daljnja Adizesova istraživanja (1988) ukazuju kako se rast i starenje očituju u odnosu fleksibilnosti (ovlaštenja) i kontroliranosti (odgovornosti) unutar poduzeća. Poduzeća su na početku poslovanja jako fleksibilna, odnosno zaposlenici imaju veća ovlaštenja, ali ne mogu uvijek kontrolirati (manja je odgovornost uprave). Kako poduzeće sazrijeva mogućnost kontrole raste, a fleksibilnost opada što se osjeća u zrelijim stadijima poslovanja. Važno je napomenuti kako veličina i vrijeme nisu uzroci starenja poduzeća. Pod pojmom „mlado poduzeće” podrazumijeva se poduzeće koje se može relativno lako promijeniti, ali je teško predvidjeti buduće događaje zbog niskog stupnja kontrole. Termin „stari” označava poduzeće čije se ponašanje može kontrolirati, ali je nefleksibilno te je sklonost promjenama poduzeća mala. Niti jedan sustav - bilo ljudski, poslovni ili tehnički - ne može istovremeno biti maksimalno fleksibilan is maksimalnom sposobnosti održavati kontrolu nad procesima (Adizes, 2006; Bogdan, 2006).

Ichak Adizes proširio je životni ciklus poduzeća na deset faza. Rast počinje prvom fazom - udvaranjem, koja obuhvaća period dok poduzeće još ne postoji, ali postoji ideja da se poslovanje oformi. Osnivači traže partnere, prezentiraju im plan poslovanja i sl. Ukoliko osnivanje ne prođe test realnosti jer s prvim naznakama problema nestaje posvećenost osnivača, završava kao flert. Slijedi doba povoja kao uspješan početak poslovanja, druga faza, koja je vezana za pronalaženje prostora za rad, povećanje troškova poslovanja. Poduzeće nagomilava poslove, brzo reagira na pritužbe klijenata i čini sve kako bi postiglo određenu reputaciju. Među zaposlenicima vladaju prisni odnosi i praktički nema viših i nižih položaja, svi rade sve. U slučaju niske potražnje, uz nedostatak fokusiranja na ostvarivanje ideje zbog koje je osnovano poduzeće, ova faza može završiti kao smrt novorođenčeta. Treća faza je razdoblje go-go u kojem se stabiliziraju novčani tijekovi, posluje se vrlo brzo, ali se odlučuje intuitivno i bez iskustva. Poduzeće jako brzo raste i prostor je pretijesan. Ne postoji politika razvoja, a specijalizacije vrlo vjerojatno nema što vodi do osnivačeve zamke. Slijedi četvrta faza, tj. adolescencija u kojoj se povećava važnost upravljanja, na štetu proizvodne funkcije. Raste važnost planiranja i usklađivanja, a uprava se posvećuje jačanju organizacijske strukture. U ovoj fazi problemi mogu završiti kao rastava zbog različitih vizija nove uprave i nezadovoljnog osnivača. Peta faza je top-forma. Organizacija doživljava napon snage, prevladavaju proizvodne, upravljačke i funkcije osnivača. Zbog strategije i definiranih dugoročnih ciljeva poduzeće raste vrlo brzo i odlično se snalazi na tržištu te postiže stabilnost (Bogdan, 2006).

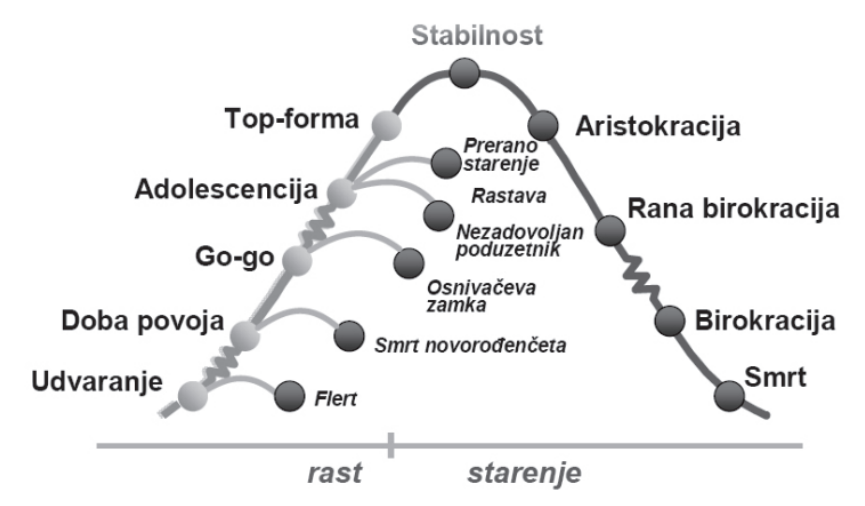

Slika 1. Životni ciklus poduzetnika po Adizesu (1988.) (Bogdan, 2006, p. 7)

U fazi stabilnosti gubi se poduzetnička funkcija, a raste integracijska. Osigurano je mjesto na tržištu. Zbog velikih prihoda odjel financija postaje važniji od odjela marketinga te istraživanja i razvoja. Sedma faza je aristokracija u kojoj moć preuzima upravljačka funkcija. Poduzeće ima reprezentativne prostore za sastanke, počinje doba zavaravanja „bolje nam je nego što je drugdje“. Slijedi osma faza, rana birokracija, do koje dolazi kada poduzeću na dulji rok nestane proizvodna i poduzetnička funkcija, a počinju se povećavati cijene proizvoda. Birokracija je deveta faza u kojoj je poduzeće okrenuto problemima unutar organizacije, a kupce se zanemaruje. Razdoblje rehabilitacije (oporavka) je dugotrajno. Posljednja, deseta faza, je smrt poduzeća, bankrot. Propadanje se odnosi na ona poduzeća koja ne uspijevaju prevladati svoje krize. Poduzeća kojima to uspije ulaze u fazu ponovnog oživljavanja (Bogdan, 2006).

Robert E. Quinn i Kim Cameron su 1983. godine razradili modele koji tipično prate promjene opisane unutar poduzeća prema unaprijed zadanoj shemi koja može biti opisana kao razvojna faza. Ove faze su uzastopne u prirodi, događaju se eksponencijalnom progresijom koju nije lagano preokrenuti i uključuju široki spektar poduzetničkih aktivnosti i struktura. Na osnovu prethodno spomenutih devet modela životnog ciklusa poduzetnika, formirali su integrativni model životnog ciklusa poduzeća koji su podijelili u četiri faze kako slijedi:

1) poduzetnička faza ili faza izgradnje poduzeća (organizacije),

2) faza kolektivnog duha ili faza rasta,

3) faza formalizacije ili faza diferencijacije, te

4) faza elaboracije (usavršavanja).

Svaka faza ima svoje značajke i svakoj od njih prijeti opasnost. Poduzeća moraju izdržati sve opasnosti (krize) jer se u protivnom njihov životni ciklus završava. Prva, poduzetnička faza vrijeme je u kojem poduzeće najčešće proizvodi jednu vrstu proizvoda ili usluga. Temeljni cilj ove faze je preživljavanje organizacije. Organizacijska struktura je najčešće neformalna i nebirokratska. S porastom broja zaposlenih počinju se javljati prve krize, kao što je kriza vođenja. Potrebna je sposobna 


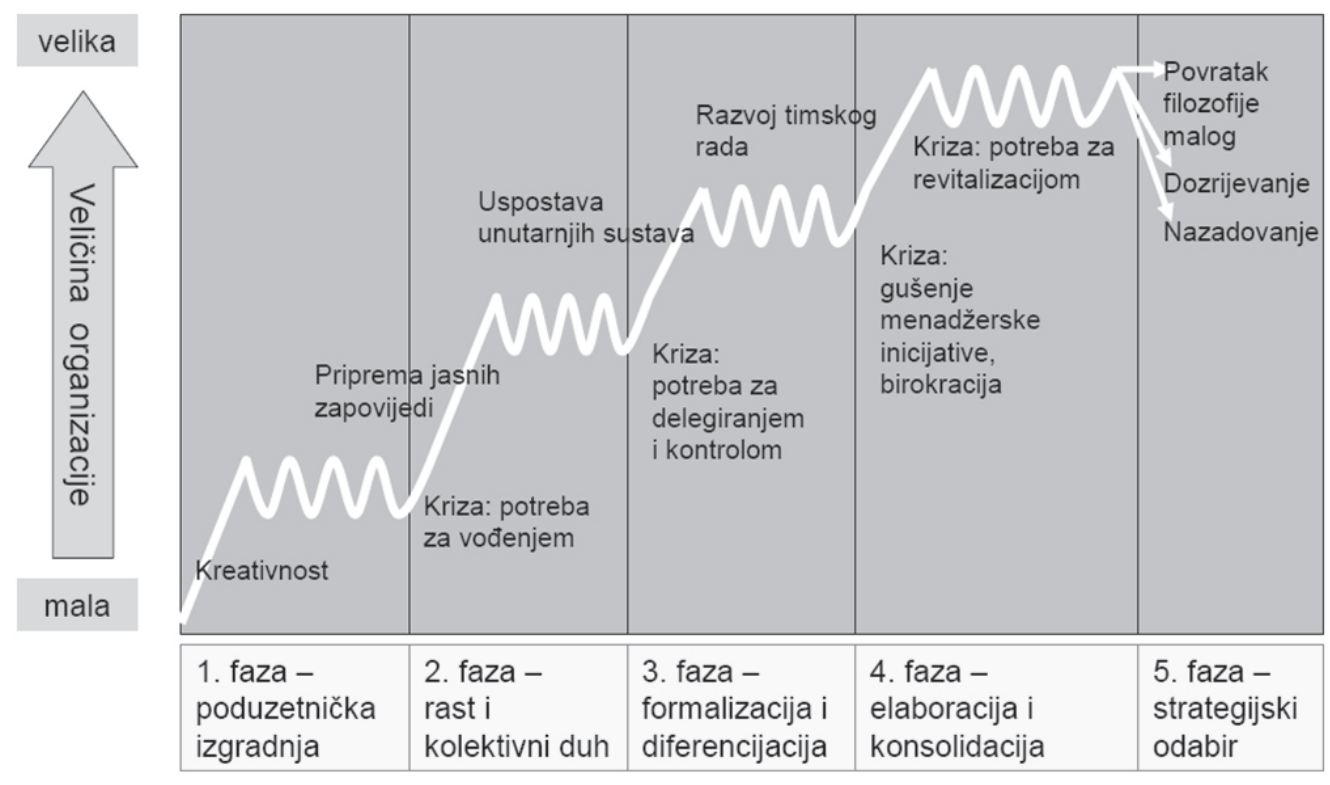

Faze u organizacijskom razvoju

Slika 2. Faze razvoja organizacije prema Quinn-u, Cameron-u i Greiner-u (Sikavica \& Novak, 1999, p. 93)

uprava koja pomaže osnivačima u izlasku iz krize, a nakon nje ostaje sposobna uprava koja redefinira ciljeve i načine rada. Nakon poduzetničke faze slijedi faza rasta (kolektivnog duha) koju karakterizira visoka kohezija i složnost u obavljanju radnih zadataka. Oblikovanje novih organizacijskih jedinica i radnih mjesta posljedica je uvođenja podjele rada. Unutar poduzeća je neformalna komunikacija i kontrola. Ponovna kriza donosi potrebu za delegiranjem. Uprava poduzeća nije sklona delegiranju poslova i podjele odgovornosti na niže razine unutar organizacije koja teže sve većoj samostalnosti. Faza formalizacije ili diferencijacije unutar poduzeća uvodi pravila, procedure i kontrolne sustave. Poduzeće se sve više birokratizira tako da je komunikacija formalna. Uprava se sve više orijentira na strateška pitanja i planiranje, a operativni poslovi se obavljaju na srednjoj razini organizacije. Kriza nastaje gušenjem inicijative na srednjoj razini organizacije poduzeća te dolazi do izražaja stabilnost $\mathrm{i}$ institucionalizacija, pa se poduzeće čini birokratizirano te preveliko da bi se moglo uspješno poslovati. Posljednju - faza elaboracije - karakterizira novi način suradnje i timskog rada. Birokracija dostiže svoj vrhunac tako što dolazi do podjele organizacije na veći broj područja kako bi se iskoristile prednosti „malih organizacija”. Dolazi do ekspanzije i decentralizacije poslovanja. Jako je važan status i reputacija poduzeća. Kriza se javlja zbog potrebe za revitalizacijom i inoviranjem (Quinn \& Cameron, 1983; Žugaj et al., 2004; Sikavica \& Novak, 1999).

Modeli životnog ciklusa poduzeća važni su zbog svojih pretpostavki i pravila. Pretpostavke modela su zahtjevi, prilike i opasnosti unutarnjih i vanjskih čimbenika poslovanja koji se mijenjaju ovisno o fazi u organizacijskom razvoju u kojoj se poduzeće nalazi. Problemi u poslovanju pojavljuju se u svim razdobljima poslovanja, ali su problemi koje se javljaju pri prelasku poduzeća iz jedne faze razvoja i/ili rasta u drugu najvjerojatniji. Na primjer, prijetnje u poslovanju razlikuju se na početku poslovanja u odnosu na zreliju fazu. Poduzeća se razvijaju kroz razvojne faze, mijenjaju u svojoj suštini, brojni zahtjevi, mogućnosti i prijetnje pritišću poduzeće na promjene u poslovanju.

\section{ZAKLJUČAK}

Od osnivanja do kraja poslovanja poduzeća, stabilnost poslovanja najviše ovisi o upravi poduzeća i njenim poslovnim sposobnostima i umijećima. Naime, uzroci problema nastaju unutar samog poduzeća, odnosno nedostatkom kontinuiranog praćenja i pravodobnih reakcija koje bi ublažile ako ne i spriječile razvoj daljnjih problema. Ekonomska kriza nije uzrok propadanja poduzeća već okidač. U radu je obrađen pojam slabljenja poslovanja te su analizirani neki od modela procesa propadanja. Nadalje, analizirani modeli organizacijskog nazadovanja povezani sa životnim ciklusom poslovanja poduzeća podijeljeni su na tri stupnja:

1) sjeme problema (eng. seed of decline),

2) neaktivnosti ili pogrešnih aktivnosti koji izazivaju krize u poduzeću, te

3) rješenja problema.

Solucije uprave na kraju svakog stadija mogu biti:

a) preobrazba,

b) povezivanje, ili

c) stečaj poduzeća.

Modeli životnog ciklusa poduzeća ne bi se trebali zanemariti pri istraživanjima pristupom case-study metodologije.

\section{LITERATURA}

Adizes, I. (2006). Životni ciklus tvrtke: kako nastaju, razvijaju se i zašto umiru dobre tvrtke, Izmijenjeno i dopunjeno izdanje, M.E.P. Zagreb: Consult.

Adler, R.W., \& Chaston, K. (2002). 'Stakeholders' perceptions of organizational decline. Accounting Forum, 26(1), 31-44.

Barković, I. (2009) Teorija poduzetništva - izazovi i perspektiva. Osijek: Pravni fakultet Osijek.

Bogdan, H. (2006). Gdje je vaša kompanija u životnom ciklusu? Adizes Southeast Europe News, br. 6, lipanj, str. 6-7. 
Cameron, K.S., Whetten, D.A., \& Kim, M.U. (1987). Organizational dysfunctions of decline. Academy of Management Journal, 30(1), 126-138.

Jones, G.R. (2009). Organizational theory, design, and change: Text and cases. Upper Saddle River, NJ: Pearson Education.

Klaić, B. (1966). Veliki rječnik stranih riječi. Zagreb: Zora.

Kovoor-Misra, S., Clair, J.A., \& Bettenhausen, K.L. (2001). Clarifying the Attributes of Organizational Crises. Technological Forecasting and Social Change, 67(1), 77-91. doi:10.1016/ S0040-1625(99)00081-5

Lippitt, G., \& Schmidt, W. (1967). Crises in a developing organization. Harvard Business Review, 45(6), 102-112.

Luecke, R. (2005). Upravljanje kriznim situacijama. Zagreb: Zgombić \& Partneri.

Novak, B. (2003). Predviđanje poslovnih teškoća banaka u Republici Hrvatskoj na osnovi javno dostupnih financijskih pokazatelja. Ekonomski pregled, 54 (11-12), 904-924.
Osmanagić Bedenik, N. (2003). Kriza kao šansa: kroz poslovnu krizu do poslovnog uspjeha. Zagreb: Školska knjiga.

Penrose, E.T. (1952). Biological Analogies In The Theory Of The Firm. American Economic Review, 42(5), 804-819.

Quinn, R., \& Cameron, K. (1983). Organizational Life Cycles And Shifting Criteria Of Effectiveness: Some Preliminary Evidence. Management Science, 29(1), 33-52.

Samuel, Y. (2009). Organizational pathology: Life and death of organizations. New Brunswick, NJ: Transaction Publishers.

Sikavica, P., \& Novak, M. (1999). Poslovna organizacija, 3. izmijenjeno i dopunjeno izdanje. Zagreb: Informator.

Žugaj, M., Šehanović, J., \& Cingula, M. (2004). Organizacija, drugo dopunjeno i izmijenjeno izdanje. Varaždin: Tiva.

THE ANALYSIS OF ORGANIZATIONAL DECLINE MODEL THROUGH LIFE-CYCLE MODELS:

\section{A LITERATURE REVIEW}

\section{Abstract:}

This paper deals with the concept and chosen models of organizational decline, also known as organizational failure. Corporate decline issues include three stages: (1) seed of decline, (2) inaction, and (3) solution which ends as a (a) organizational transformation, (b) takeover, or (c) bankruptcy. Moreover, indicators and symptoms of organizational decline are also analyzed in the paper through examining the life cycle of an enterprise in which decline is often considered a long-drawn-out process.

\section{Key words:}

organizational decline, organizational change. 